delivered as a lecture in 1854 , he described the phenomenon of levitation. Of his investigation of the second kind of phenomena, Faraday prepared a report which was published on July 2,1953 , in the Athencum, a journal devoted to English and foreign literature. science, and the fine arts, which was founded in 1828 and which continues to-day, after several mergers, as the New Statesman and Nation. A copy of this interesting report and some comments upon it have been set out in Scientific Monthly $(83$, No. 3 ; September 1956).

\section{National Science Foundation Fellowships}

THE National Science Foundation, Washington, D.C., is offering three types of fellowship awards for advanced study and research in the natural sciences during the academic year 1957-58: predoctoral fellowships for college seniors and graduates $(1,600-$ 1,800 dollars); postdoctoral fellowships for those who have already gained a doctor's degree in science $(3,800$ dollars) ; and senior postdoctoral fellowships for those who have had a doctorate for a minimum of five years and have demonstrated unusual ability for research (4,000-10,000 dollars). The awards are open to American citizens and are tenable in any non-profit institution of higher education in the United States or abroad. The fields of study may be the mathematical, physical, medical, biological, engineering and other scionces, including anthropology, psychology (other than clinical), geography, certain interdisciplinary fields, and areas of convergence between the natural and social sciences. About a thousand awards will be made and will be announced next March. Applications for predoctoral fellowships should be made by January 7, and for postidoctoral fellowships by December 24, to the Fellowship Office, National Academy of Scionces-National Research Council, 2101 Constitution Avenue, N.W., Washington 25, D.C. For senior postdoctoral fellowships application should be made by January 14 to the Division of Scientific Personncl and Education, National Science Foundation, Washington 25, T.C.

\section{Conference on the Bio'ogy of the Hair Follicle} and the Growth of $\mathrm{Har}$

AN international conference on "The Biology of the Hair Follicle and the Growth of Hair" will be held under the auspices of the British Society for Research on Ageing at the Royal Society of Medicine during August 7-9, 1957. The Congress will deal with the grcss and microscopic anatomy and histochemistry of the hair follicle and the hair, studies on mitoses of the hair follicle and effects of nutrition and hormones on hair growth, vascularity and patterns of growth, production of pigment, regeneration and de novo formation of hair follicles. Admission is by ticket, obtainable free of charge from the Honorary Secretary, British Society for Research on Ageing, Dr. G. FT. L'ourne, London Hospital Medical College, Whitechapel, London, E.1.

\section{Announcements}

DR. J. R. Price, senior principal research officer in the Organic Chemistry Section of the Commonwealth Scientific and Industrial Research Organization, Australia. has been awarded the H. G. Smith Memorial Modal for 1956 of the Royal Australian Chemical Institute. The Medal is for contributions over the past ten years to the development of chemical science in the field of organic chemistry and biochemistry, and the award to Dr. Price is for his researches on several types of compounds, and especially on the alkaloids.

The Meldola Medal, which is the gift of the Society of Maccabæans, is being offered for award early in 1957 to the chemist who, being a British subject and less than thirty years old on December 31, shows the most promise, as indicated by published chemical work brought to the notice of the Council of the Royal Institute of Chemistry before December 31 . Communications should be addressed to the President, Royal Institute of Chomistry, 30 Russell Square, London, W.C.l, the envelope being marked "Meldola Medal".

SIR Georat BeItby Memorial awards, which are considered at intervals by administrators representing the Royal Institute of Chemistry, the Society of Chemical Industry and the Institute of Metals, are made to British scientific research workers, preference being given to investigations relating to the special interests of Sir George Beilby, including fuel economy, chemical engineering and metallurgy. In general, the awards are given to younger workers for original investigations over a number of years. For awards early in 1957, the attention of the administrators should be directed, before December 31, to work of the nature indicated, all communications being addressed to the Convenor of the Administrators, Sir George Beilby Memorial Fund, Royal Institute of Chemistry, 30 Russell Square, London, W.C.1.

Dr. R. CockBurN, deputy controller of electronics, Ministry of Supply, has been appointed controller of guided weapons and electronics in the Ministry.

MR. C. E. LAMBERT, representing the Colonial Territories, has been elected chairman of the Executive Council of the Commonwealth Agricuitural Bureaux, in succession to Mr. J. E. C. Coventry, who represented the Federation of Rhodesia and Nyasaland. Lieut.-Colonel V. A. Nicholas, representing Ceylon, has succeeded $\mathrm{Mr}$. Lambert as vice-chairman.

Proz. F. A. Gregory, of the Research Institute of P'lant Physiology, Imperial College of Science and Technology, London, will deliver the Amos Memorial Lecture at the East Malling Research Station, Kent, on November 15. He will speak on "The Place of Plant Physiology in Fruit-growing”.

PROF. R. B. WOODWARn, professor of chemistry, Harvard University, will deliver the eighth annual Ciba Foundation Lecture on December 5 at 5 p.m. in the meeting room of the Zoological Society of London; his subject will be "Recent Advances in the Chemistry of Natural Products". Admission is by ticket only, obtainable from the Assistant Secretary, The Ciba Foundation, 41 Portland Place, London, W.l.

A ONE-DAY conference on "Automation, Education and Training" is being organized by the Eritish Association for Commercial and Industrial Education, and will be held in the Royal Festival Ilall, London, on December 4. Particulars can be obtained from the Association, at Management House, 8 Hill Street, London, W.1.

Erratum. In the communication entitled "Antagonists of the Action of Reserpine on Smooth Muscle" in Nature of October 20, p. 859, col. 2, par. 2, line 3, for "serotonin (15-40 mgm. per ml.)" read "serotonin (15-40 nanograms per $\mathrm{ml}$.$) ".$ 